\title{
Keeping health on the political agenda
}

\author{
Vitor Teixeira
}

Affiliation: European Respiratory Society, Brussels, Belgium.

Correspondence: Vitor Teixeira, ERS Brussels Office, EU Affairs, Rue de Tréves 49-51, BE-1040, Brussels, Belgium. E-mail: vitor.teixeiradersnet.org

0 @ERSpublications

ERS and its ECDA partners met the new EU Health Commissioner to discuss a future EU framework on chronic diseases http://ow.ly/GnVBM

Having already survived an attempted ousting, Jean-Claude Juncker, the new European Commission President only took office on November 1, 2014, together with his college of Commissioners representing each member state [1]. Having previously won the direct backing of Members of the European Parliament to lead the Commission, he was forced to face down this first challenge before even having the opportunity to reveal his first work plan for 2015 [2].

The new Commission President is keen to break down barriers between different policy areas from the start of his mandate [3]. This should be good news for health, which is often side-lined in favour of other priorities, but closer examination may prove this not to be case.

President Juncker's political agenda is built around 10 main policy areas to bring about "jobs, growth, fairness, and democratic change" [4]. While none of Juncker's 10 goals explicitly refers to health, the impact of politics on health cannot be underestimated. From the quality of the air we breathe, to the legalisation and pricing of tobacco products, and even to the amount of money spent on health research, health concerns extend far into other policy areas. Scientific and medically driven health advocacy at the European Union (EU) level will therefore remain crucial to keeping health on the political agenda.

Advocacy has always been a key pillar of the European Respiratory Society (ERS), and we work to promote lung health and build alliances with partner medical and scientific organisations to strengthen our actions further [5]. ERS is a member of several health alliances, such as the European Chronic Disease Alliance (ECDA). This is an alliance of 11 health organisations that works on behalf of millions of patients and over 200000 health professionals, representing all major noncommunicable chronic diseases (NCDs) [6].

One benefit of such an alliance is that it provides even greater opportunities to deliver our messages to high-level officials and policy makers, the most recent example being a meeting between ECDA members and the European Commissioner for Health and Food Safety, Vytenis Andriukaitis (fig. 1). EU Affairs Secretary Jean-Paul Sculier represented ERS to discuss the alarming rise of NCDs, which are responsible for $86 \%$ of deaths and $77 \%$ of the disease burden in Europe, the region of the world that is most afflicted by NCDs $[7,8]$.

Dr Andriukaitis, a former Health Minister of Lithuania, is a valuable partner for ERS and also colourful character in the grey of Brussels. He is a qualified cardiovascular surgeon and a historian, having lectured on both history and political science at Vilnius University $[9,10]$. He began his political career at the end of the 1970s, when he was involved in the underground anti-Soviet movement in Lithuania. He was a founder of the Social Democratic Party of Lithuania, and went on to become a signatory of the Act of Independence of the Republic of Lithuania and a co-authored its Constitution. With 18 years of experience as Member of the Lithuanian Parliament, he is a highly experienced politician, who served for 2 years as Health Minister before taking his position as European Commissioner for Health and Food Safety. Dr Andriukaitis has a well-established reputation in the area of health policy, which was recognised by his

Received: Dec 122014 | Accepted after revision: Dec 172014

Conflict of interest: V. Teixeira is an employee of the European Respiratory Society.

Copyright CERS 2015 
FIGURE 1 European Chronic Disease Alliance representatives, including European Respiratory Society Secretary for European Union (EU) Affairs Prof. Jean-Paul Sculier, meeting with the new EU Commissioner for Health and Food Safety, Dr Vytenis Andriukaitis.

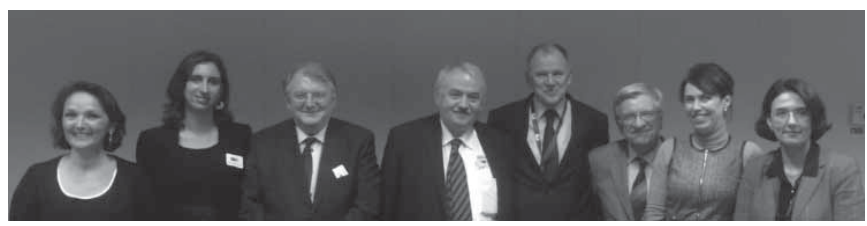

appointment as Vice-President of the 67th World Health Assembly and further strengthened by the fact that he was the first health commissioner to have actively requested the position.

Encouragingly, Dr Andriukaitis confirmed, for spring 2015, a follow-up event to last April's EU Summit on Chronic Diseases, at which ERS President Elisabeth Bel spoke on behalf of the respiratory community [6]. This event will take place in view of the possible future development of a cooperative structure on chronic diseases. The Commission invited ERS to submit their positions on such a structure, addressing questions such as the following. 1) What should such a "cooperative structure on Chronic Diseases" look like? 2) What are the most urgent content and activities for a cooperative structure on chronic diseases? 3) What would be a suitable modus operandi of a cooperative structure on chronic diseases in terms of operations, financing, implementation, reporting, evaluation and dissemination of actions?

President Juncker has nominated a highly experienced and highly motivated health champion as Health Commissioner, but it is up to health professionals and organisations such as ERS to support and assist his work at the European level. All ERS members play a role in keeping health on the political agenda. To engage with policy makers and political actors, reliable scientific evidence, medical expertise and experience, and an independent voice are essential. ERS advocacy bases its arguments on these values and will continue to do so to ensure that lung health counts.

\section{References}

1 European Commission. Press Release Database. Juncker Commission takes office. http://europa.eu/rapid/ press-release IP-14-1237 en.htm Date last accessed: December 4, 2014.

2 Europe of Freedom and Direct Democracy. Newsroom. Motion of Censure to sack Juncker Commission submitted by members of EFDD Group. www.efdgroup.eu/newsroom/press-releases/item/motion-of-censure-to-sack-junckercommission-submitted-by-members-of-efdd-group?category_id=9 Date last accessed: December 4, 2014. Date last updated: November 18, 2014.

3 European Commission. Press Release: The Juncker Commission: a strong and experienced team standing ready for change. http://europa.eu/rapid/press-release_IP-14-984_en.htm Date last accessed: December 4, 2014.

4 Juncker JC. A new start for Europe: my agenda for jobs, growth, fairness and democratic change. http://ec.europa. eu/about/juncker-commission/docs/pg_en.pdf Date last accessed: November 26, 2014. Date last updated: July 15, 2014.

5 European Respiratory Society. The European Respiratory Society Constitution. www.ersnet.org/images/stories/pdf/ Constitution_ADOPTED_in_Vienna_2012.pdf Date last accessed: December 4, 2014.

6 Kamel N. The Growing chronic disease burden in Europe: a role for respiratory health professionals? Eur Respir J 2014; 43: 1249-1251.

$7 \quad$ World Health Organization Regional Office for Europe. Action plan for implementation of the European Strategy for the Prevention and Control of Noncommunicable Diseases 2012-2016. Copenhagen, World Health Organization, 2012.

8 World Health Organization Regional Office for Europe. Health 2020: a European policy framework and strategy for the 21st century. Copenhagen, World Health Organization, 2013

9 European Commission. The Commissioners - Vytenis Andriukaitis. http://ec.europa.eu/commission/2014-2019/ andriukaitis_en Date last accessed: December 4, 2014.

10 European Parliament. New Commission - hearings: Vytenis Andriukaitis CV. www.elections2014.eu/en/newcommission/hearing/20140917HEA64709 Date last accessed: December 4, 2014 